\title{
Mortality among critically ill patients with methicillin-resistant Staphylococcus aureus bacteremia: a multicenter cohort study in Colombia
}

\author{
Juan S. Castillo, ${ }^{1}$ Aura L. Leal, ${ }^{2}$ Jorge A. Cortes, ${ }^{3}$ Carlos A. Alvarez, ${ }^{3}$ \\ Ricardo Sanchez, ${ }^{1}$ Giancarlo Buitrago, ${ }^{1}$ Liliana I. Barrero, ${ }^{1}$ \\ Andrés L. Gonzalez, ${ }^{1}$ Daibeth H. Henriquez, ${ }^{4}$ on behalf of GREBO ${ }^{5}$
}

Suggested citation

Castillo JS, Leal AL, Cortes JA, Alvarez CA, Sanchez R, Buitrago G, et al. Mortality among critically ill patients with methicillin-resistant Staphylococcus aureus bacteremia: a multicenter cohort study in Colombia. Rev Panam Salud Publica. 2012;32(5):343-50.

ABSTRACT Objective. To evaluate risk factors associated with methicillin-resistant Staphylococcus aureus (MRSA) bacteremia emergence, its prognosis, and mortality-determining factors in critically ill patients in Colombia.

Methods. A multicenter, retrospective cohort study conducted in 2005-2008 at 16 public and private reference health care institutions in Bogota, Colombia, that form part of a national epidemiological surveillance network and a hospital network with 4469 beds. Methicillinresistant emergence and mortality were analyzed using descriptive and time-to-event analysis; a multivariate Cox proportional hazard regression model was built to test the association between methicillin resistance and mortality.

Results. A total of 372 patients were studied: 186 with MRSA bacteremia, randomly matched with 186 with methicillin-susceptible Staphylococcus aureus (MSSA) bacteremia. Previous surgery, antibiotic exposure, and hospital-acquired infections were independently associated with methicillin resistance. MRSA caused longer hospital stays among survivors (median 24 versus 18 days, $\mathrm{P}=0.014$ ). Mortality predictors were: patient age, creatinine level over $1.21 \mathrm{mg} / \mathrm{dl}$ at ICU admission, severe sepsis, and inotropic requirement. Appropriate antimicrobial therapy and antimicrobial therapy change were independent protective factors, as was male gender.

Conclusions. Methicillin resistance per se was not a mortality-independent prognostic factor. Previous conditions, such as age, baseline renal impairment, severe sepsis, and inotropy demand explained the observed mortality. Appropriate antimicrobial therapy remained a protective factor. A call to improve infection control measures in Colombia is mandatory.

Key words

Bacterial infections; methicillin-resistant Staphylococcus aureus; outcome assessment (health care); risk factors; mortality; Colombia.

${ }^{1}$ Grupo de investigación en enfermedades infecciosas, Facultad de Medicina, Universidad Nacional de Colombia, Bogotá, Colombia. Send correspondence to Juan Castillo Londoño, jscastillol@unal.edu.co

2 Departamento de microbiología, Facultad de Medicina, Universidad Nacional de Colombia, Bogotá, Colombia.
${ }^{3}$ Departamento de medicina interna, Facultad de Medicina, Universidad Nacional de Colombia, Bogotá, Colombia.

4 Ârea de vigilancia epidemiológica, Departamento de salud pública, Secretaria Distrital de Salud, Bogotá, Colombia.

${ }^{5}$ Grupo para el Control de la Resistencia Bacteriana, Bogotá, Colombia.
Since its emergence in hospital environments (1), methicillin-resistant Staphylococcus aureus (MRSA) has become a serious public health problem that has spread worldwide. In most countries, MRSA is an important con- 
cern for hospital infection-control programs, especially in the Intensive Care Units (ICU), where it can cause severe complications (2-4). As a cause of bacteremia, an MRSA can be related to poor outcomes for the patient, the patient's family, and the healthcare providers $(5,6)$.

The relationships between methicillin resistance and mortality, morbidity, prolonged length of stay, and higher hospital costs have been widely studied (7-9). Risk factors for MRSA development in the ICU setting have been analyzed, and invasive device exposure, hospital acquired infections, and previous antimicrobial treatment are well recognized as predisposing conditions $(5,10)$. On the other hand, some reports have studied the effect of MRSA on clinical outcomes, especially mortality (11). However, there has been wide variability in methodology, sample size, confounding variables, and data analysis strategies (12-20).

A consistent conclusion on MRSAassociated mortality in the ICU cannot be reached with the available evidence; however, some prognosis factors have been established for negative outcomes of MRSA bacteremia. Some reports have discussed the role of baseline comorbidities, illness severity, cardiovascular impairment, and multiorganic dysfunction as predictors of hospital mortality (12-15, 17). Recent literature has brought into question the protective function of adequate, initial antimicrobial therapy, and its timely implementation after bacteremia onset (20-22).

The present study evaluates risk factors associated with MRSA bacteremia emergence, its prognosis, and mortality-determining factors in critically ill patients in Colombia.

\section{METHODS}

\section{Study setting}

A retrospective cohort study was conducted at 16 public and private reference health care institutions in Bogotá, Colombia. All institutions belonged to an epidemiological surveillance network that receives and processes microbiological data from hospitals around the country. During the observation period, the hospital network had 4469 beds and reported 347 active beds for medical, cardiovascular, pediatric, and burn intensive care services. Hospital capacity ranged from 46-630 beds.

\section{Data collection}

All critical care isolations of MRSA bacteremia among in-patients at least 16 years of age at participating institutions in January 2005-December 2008 were identified and matched (1:1 ratio), by hospital and year, with a randomlyselected sample of patients with methicillin-susceptible Staphylococcus aureus (MSSA) bacteremia. Clinical information was extracted from medical records by a team of trained physicians who consulted with one of the infectious disease specialists in the group (JAC, CAA, ALL). A list of random numbers was used to select the unexposed group in each participating institution. Patients with polymicrobial bacteremias were excluded.

Sample size was calculated assuming an effect size for oxacillin equivalent to a hazard ratio (HR) of 1.5 , with a theoretical event frequency of $50 \%$, an alpha value of 0.05 , and a sample power of $80 \%$ for a two-tailed hypothesis test. In a 1:1 ratio, a sample size of 382 subjects was adequately powered to observe a difference in the survival function expressed by an HR of 1.5 .

The institutional review board of the School of Medicine at the Universidad Nacional de Colombia (National University of Colombia, Bogotá, Colombia) approved the study protocol in August 2007. In addition, all participating institutions independently approved their own participation in the study.

\section{Definitions and variables}

An episode of $S$. aureus bacteremia was defined according to the criteria established by the Centers for Disease Control and Prevention (CDC, Atlanta, Georgia, United States) as an isolation of the target pathogen with signs or symptoms of infection and without other simultaneous micro-organisms. The source of bacteremia, as well as of co-infections, was defined using the same guidelines (23). Furthermore, the source of infection was classified as eradicable and non-eradicable according to the availability of any intervention intended to remove it (i.e., catheter withdrawal, peritoneal lavage, abscess drainage, tissue resection, prosthesis removal, and others.)

Health care-associated infection was defined using Friedman's criteria (24). Bacteremia occurring 48 hours after hospitalization was considered nosocomial, and so were infections related to an implant or device used in the previous year.

Death was considered directly attributable to bacteremia if the patient, in the absence of any other reasonable explanation, presented signs or symptoms of bacteremia in the 7 days preceding death or had an active infection in another location caused by the same micro-organism (25). If the patient did not present a likely cause of death, bacteremia was still considered the probable cause of death (7).

Adequate antimicrobial treatment was defined as administration of the microbiological agent pertinent to reported resistance profile within the first 48 hours of the bacteremia onset in the appropriate manner, frequency, dose, and duration.

\section{Comorbidity}

Baseline risk of death and severity of disease at ICU admission time was assessed using the Acute Physiology and Chronic Health Evaluation II (APACHE II) score and the McCabe classification, respectively $(26,27)$. Comorbid conditions were measured using the Charlson index (28). International Sepsis Definition Conference criteria were used for all infection-related outcomes (29). Patients were considered immunocompromised if any pre-stated conditions (i.e., acquired immunodeficiency syndrome, autoimmune disease, cancer, chemotherapy, chronic renal failure, cirrhosis, high-dose steroid treatment, severe burns, severe malnourishment, transplantation, or uncontrolled diabetes mellitus) were documented in the 30-day period preceding bacteremia. Clinical background, such as hospitalizations, invasive devices, use of antibiotics, and surgical procedures, were also recorded.

\section{Microbiological methods}

Staphylococcus aureus isolation and typing were done in all participating laboratories according to standardized techniques. Antimicrobial susceptibility 
was performed by an automated microdilution method using either VITEK $^{\circledR}$ (bioMérieux Inc., Marcy l’Étoile, France) or MicroScan ${ }^{\circledR}$ (Siemens Healthcare Diagnostics Inc., Tarrytown, New York, United States).

Methicillin resistance was defined as a minimum inhibitory concentration of $4 \mathrm{mg} / \mathrm{L}$ accordingly to Clinical and Laboratory Standards Institute criteria (30). Participating hospitals did not routinely perform a Cefoxitin confirmatory test.

\section{Statistical analyses}

The main outcome was overall mortality, defined as death by any cause during the first 30 days of bacteremia. Discrete variables were expressed as frequencies (percentages) and continuous variables as means (with standard deviation) or medians (with inter-quartile range) according to data distribution. Comparative analyses between proportions were done with the Chi-square test or Fisher's exact test; and the Student's t test or Wilcoxon's rank sum test were used for the continuous variables, as appropriate.

To evaluate variables associated with MRSA resistance, logistic regression was done using resistance or susceptible micro-organisms as outcome. To study the influence of methicillin resistance and other variables on overall mortality, a Cox proportional hazard regression was performed. Survival rates per 1000 patients/day were calculated, and Kaplan Meier survivor functions were estimated and compared between different groups using the log rank test. Variables with $P$ value $<0.10$ in bivariate analyses or those with a plausible biological relationship to the outcome were considered in multivariate modeling. Starting from a full model, variables were added and removed using a stepwise approach (31). Some predictors were restricted according to correlation test in order to avoid collinearity using a correlation coefficient greater than 0.70 . Two independent models were constructed, one forcing the introduction of methicillin resistance and the other without the presence of this variable; models were contrasted with a likelihood ratio test. Hazard ratios with 95\% Confidence Intervals (95\% CI) were reported. Proportional hazard assumption was evaluated both graphically and statistically using Schoenfeld residuals, and time dependent covariates were con- sidered in final models. All tests were two-tailed and $P<0.05$ was considered to indicate statistical significance. All analyses were performed using Stata ${ }^{\circledR}$ version 11.1 (StataCorp LP, College Station, Texas, United States).

\section{RESULTS}

A total of 372 patients were included in the study; 186 with MRSA bacteremia matched 1:1 with 186 with MSSA. Of the study population, those 65 years of age and older represented $43.8 \%$. No important differences in age, sex, or baseline severity were observed; however, previous surgery, previous antibiotic use, invasive devices, or hospital environment exposure were more frequent in MRSA patients. Comparison of baseline characteristics among exposed groups is shown in Table 1. Logistic regression showed that previous surgery (Odds Ratio $[\mathrm{OR}]=2.55 ; 95 \% \mathrm{CI}: 1.59-4.08)$, previous antibiotic exposure $(\mathrm{OR}=4.05$; 95\%CI: 2.31-7.14), and hospital-related bacteremia were risk factors for MRSA emergence (Table 2).

Median survival time was 28 days for the entire cohort. Compared to MSSAinfected patients, MRSA was associated with longer hospital stays among survivors (median 30 days vs. 21 days, $P<0.001)$ and a higher risk of global hospital mortality (57\% vs. $46.2 \%, P=$ 0.038). A total of 192 patients died during hospitalization, corresponding to a general mortality rate of 29.64 per 1000 patient-days. A clinical, but not statistically significant, attributable mortality was observed in MRSA contrasted with MSSA (71.7 vs. $57 \%, P=0.097$ ). Mortality rates were significantly higher in women (40.02 per 1000 patient-days), patients 65 years of age and older (43.10), and those with septic shock (53.91), multiple organ failure (65.88), creatinine more than 1.21 $\mathrm{mg} / \mathrm{dL}$ at ICU admission (46.31), and initial inappropriate treatment (43.54) (Table 3). Despite the presence of a gradient according to risk categories for severity indicators, such as APACHE II and McCabe at ICU admission, these differences were not statistically significant.

Cox proportional hazard model results are summarized in Table 4. Variables associated with an increased risk of overall mortality were older age, creatinine level at ICU admission more than 1.21 $\mathrm{mg} / \mathrm{dL}$, presence of severe sepsis, and inotropic requirement. Methicillin resistance was not an independent prognostic factor for mortality once adjusted for other predictors. Independent protective factors were initial, adequate treatment; antibiotic change during infection; and being male.

\section{DISCUSSION}

This study showed a clinical, but not statistically-significant, difference in mortality in MRSA bloodstream infections when compared to MSSA bacteremia in critical care patients. Risk factors for methicillin resistance identification were related to previous health care exposure. Risk factors for mortality among patients with $S$. aureus bacteremia can be classified into three categories: those related to the micro-organism, those related to the affected individual (comorbidity), and those related to the severity of the infection (clinical status at admission). Contrasted with previous research in critical care settings $(13,15,16,18,32)$, these results did not register an independent effect of methicillin resistance phenotypes on overall mortality. Lack of methicillin resistance effect on unfavorable outcomes could be explained by the effect of other predictors as set out in non-exclusive ICU comparisons $(6,8)$ and ICU comparisons (19). On the other hand, initial adequate treatment, as reported in previous studies, represented an important protective factor against MRSA mortality (20) and an indirect indicator of the effect of the antimicrobial resistance. Previous evidence suggests that MRSA isolation and length of hospital stay are important risk factors in the event of inappropriate empirical antimicrobial treatment (33). Independent effect of recognized mortality predictors, such as age $(10,13,19,34)$, gender (35), creatinine level at ICU admission (36), shock, and sepsis with at least one organ impairment (33), were seen in critical care patient populations.

These findings, however, agreed with other multicenter studies, and confirmed the prognostic significance of severity gradation from sepsis, severe sepsis, and shock as forms to evaluate clinical presentation at admission (37). Some correlation between severe sepsis and multiorganic dysfunction; and septic shock and inotropic requirement was documented. It leads to restriction of 
TABLE 1. Comparison of patients' baseline characteristics according to their methicillin resistance profile in a hospital network in Colombia, 2005-2008

\begin{tabular}{|c|c|c|c|c|c|c|c|}
\hline \multirow[b]{2}{*}{ Characteristic $^{\mathrm{a}}$} & \multicolumn{2}{|c|}{$\operatorname{MSSA}^{\mathrm{b}}(n=186)$} & \multicolumn{2}{|c|}{$\operatorname{MRSA}^{c}(n=186)$} & \multicolumn{2}{|c|}{ Total $(n=372)$} & \multirow[b]{2}{*}{$P$ value } \\
\hline & No. & $\%$ & No. & $\%$ & No. & $\%$ & \\
\hline Age in years [mean $\left(\mathrm{SE}^{\mathrm{d}}\right)$ ] & 57.9 & 1.4 & 57.7 & 1.4 & 57.8 & 3.0 & 0.900 \\
\hline Sex (male) & 105 & 56.5 & 116 & 62.4 & 221 & 59.4 & 0.245 \\
\hline Referred & 83 & 44.6 & 90 & 48.4 & 173 & 46.5 & 0.467 \\
\hline Type of referring institution & & & & & & & 0.247 \\
\hline Hospital & 77 & 92.8 & 77 & 86.5 & 154 & 89.5 & \\
\hline Home care service & 0 & 0 & 2 & 2.2 & 2 & 1.2 & \\
\hline Ambulatory & 6 & 7.2 & 10 & 11.2 & 16 & 9.3 & \\
\hline \multicolumn{8}{|l|}{ Clinical background } \\
\hline Immunosuppression & 85 & 45.7 & 94 & 50.5 & 179 & 48.1 & 0.350 \\
\hline Previous surgery & 73 & 39.2 & 125 & 67.2 & 198 & 53.2 & $<0.001$ \\
\hline Hospitalization in the last year & 87 & 46.8 & 103 & 55.4 & 190 & 51.1 & 0.312 \\
\hline Previous antibiotic exposure & 115 & 62.5 & 164 & 88.6 & 279 & 75.6 & $<0.001$ \\
\hline Previous invasive device & 160 & 86 & 179 & 96.2 & 339 & 91.1 & 0.001 \\
\hline LOSe before bacteremia (days) [median (IQR $\left.\left.{ }^{f}\right)\right]$ & 5 & $(1-9)$ & 12 & $(2-15)$ & 7 & $(13-13)$ & $<0.001$ \\
\hline APACHE II score [median (IQR $\left.{ }^{f}\right)$ ] & 15 & $(10-20)$ & 15 & $(11-22)$ & 15 & $(11-21)$ & 0.4085 \\
\hline Charlson score $>3$ & 94 & 50.5 & 94 & 50.5 & 188 & 50.5 & 1.000 \\
\hline Baseline serum creatinine (mg/dL) & 1.1 & 1.41 & 1.07 & 1.18 & 1.1 & 1.23 & 0.406 \\
\hline McCabe classification & & & & & & & 0.571 \\
\hline Rapidly fatal & 11 & 5.9 & 9 & 4.8 & 20 & 5.4 & \\
\hline Ultimately fatal & 80 & 43 & 72 & 38.7 & 152 & 40.9 & \\
\hline Nonfatal & 95 & 51.1 & 105 & 56.5 & 200 & 53.8 & \\
\hline Place of bacteremia acquisition & & & & & & & 0.005 \\
\hline Community or $\mathrm{AH}^{\mathrm{g}}$ & 36 & 19.3 & 13 & 7 & 49 & 13.2 & \\
\hline Referent institution & 26 & 14 & 26 & 14 & 52 & 14 & \\
\hline Index hospital, non ICU & 34 & 18.3 & 42 & 22.6 & 77 & 20.7 & \\
\hline Index hospital, ICU & 90 & 48.4 & 105 & 56.4 & 194 & 52.1 & \\
\hline Source of bacteremia & & & & & & & 0.348 \\
\hline Central venous catheter & 67 & 50.7 & 72 & 56.7 & 139 & 53.6 & \\
\hline Respiratory tract & 32 & 24.2 & 24 & 18.9 & 56 & 21.6 & \\
\hline Surgical site & 4 & 3 & 8 & 6.3 & 12 & 4.6 & \\
\hline Skin and soft tissue & 12 & 9.1 & 10 & 7.9 & 22 & 8.5 & \\
\hline Unknown & 54 & 29 & 59 & 31.7 & 113 & 30.4 & \\
\hline Classification of source & & & & & & & 0.998 \\
\hline Eradicable & 86 & 47 & 85 & 46.7 & 171 & 46.8 & \\
\hline Non-eradicable & 97 & 53 & 97 & 53.3 & 194 & 53.2 & \\
\hline \multicolumn{8}{|c|}{$\begin{array}{l}\text { a Variables are stated as frequency (number and percentage) unless otherwise specified. } \\
\text { b Methicillin-susceptible Staphylococcus aureus. } \\
\text { c Methicillin-resistant Staphylococcus aureus. } \\
\text { d Standard error. } \\
\text { e Length of stay. } \\
\text { Inter-quartile range (25th percentile-75th percentile). } \\
\text { g Ambulatory health care. }\end{array}$} \\
\hline
\end{tabular}

TABLE 2. Bivariate and multivariate analysis of risk factors related to methicillin resistant Staphylococcus aureus bacteremia in a hospital network in Colombia, 2005-2008

\begin{tabular}{|c|c|c|c|c|}
\hline Risk factor & $\mathrm{OR}^{\mathrm{a}}$ & $95 \% \mathrm{Cl}^{\mathrm{b}}$ & $\mathrm{AOR}^{\mathrm{C}}$ & $95 \% \mathrm{Cl}$ \\
\hline Age (> 65 years) & 1.16 & $0.77-1.76$ & - & - \\
\hline Sex (male) & 1.28 & $0.84-1.94$ & - & - \\
\hline Immunosuppression & 1.21 & $0.81-1.82$ & - & - \\
\hline Hospitalization in the last year & 1.32 & $0.77-2.26$ & - & - \\
\hline 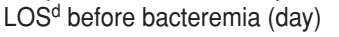 & 1.08 & $1.06-1.11$ & - & - \\
\hline Previous invasive device & 4.16 & $1.76-9.83$ & - & - \\
\hline Previous surgery & 3.17 & $2.08-4.85$ & 2.55 & $1.59-4.08$ \\
\hline Previous antibiotic exposure & 4.69 & $2.72-8.07$ & 4.06 & $2.31-7.14$ \\
\hline \multicolumn{5}{|l|}{ Place of bacteremia acquisition } \\
\hline Community or $\mathrm{AH}^{\mathrm{e}}$ & 1 & 1 & 1 & 1 \\
\hline Referent institution & 2.77 & $1.20-6.38$ & 2.77 & $1.15-6.70$ \\
\hline Index hospital, non-ICUf & 3.42 & $1.57-7.45$ & 2.68 & $1.17-6.14$ \\
\hline Index hospital, ICU & 3.23 & $1.61-6.47$ & 2.65 & $1.27-5.54$ \\
\hline
\end{tabular}

a Odds ratio.

b $95 \%$ confidence interval.

c Adjusted odds ratio.

d Length of stay.

e Ambulatory health care.

$f$ Intensive care unit. less significant predictors in the final model. Although some limitations can be expected from a non-standardized procedure for measurement of creatinine levels, this factor and sepsis severity constituted important predictors of general mortality and do not show collinearity with other predictors. Some controversy exists in recent literature regarding gender differences in mortality $(10,38)$; biological factors and comorbid conditions can be reasonable explanations for this discrepancy.

Some studies have found an explanatory effect of baseline severity on hospital mortality rate $(13,19)$. The present study did not observe any important, independent effect of the McCabe classification or the APACHE II score on mortality. Nonetheless, with bivariate 
TABLE 3. Bivariate analysis of mortality rates by predictor for Staphylococcus aureus bloodstream infections in critically ill patients from a hospital network in Colombia, 2005-2008

\begin{tabular}{|c|c|c|c|c|}
\hline Mortality predictor & Patients & Mortality rate ${ }^{a}$ & $95 \% \mathrm{Cl}^{\mathrm{b}}$ & $P$ value $^{\mathrm{c}}$ \\
\hline Overall & 372 & 29.64 & $25.4-34.59$ & \\
\hline Sex & & & & 0.0052 \\
\hline Male & 151 & 24.17 & $19.57-29.86$ & \\
\hline Female & 221 & 40.02 & $31.92-50.19$ & \\
\hline Age (years) & & & & $<0.0001$ \\
\hline $15-64$ & 209 & 21.23 & $16.83-26.79$ & \\
\hline$\geq 65$ & 163 & 43.10 & $35.06-53.00$ & \\
\hline Methicillin resistance & & & & 0.0697 \\
\hline Susceptible & 186 & 25.73 & $20.29-32.63$ & \\
\hline Resistant & 186 & 33.34 & $27.21-40.86$ & \\
\hline Previous surgery & & & & 0.0797 \\
\hline No & 174 & 35.09 & $28.18-43.68$ & \\
\hline Yes & 198 & 25.70 & $20.67-31.95$ & \\
\hline Multiple organ failure & & & & $<0.0001$ \\
\hline No & 184 & 9.54 & $6.74-13.49$ & \\
\hline Yes & 167 & 65.88 & $54.96-78.96$ & \\
\hline Classification of source & & & & 0.0973 \\
\hline Eradicable & 194 & 33.03 & $26.86-40.61$ & \\
\hline Non eradicable & 171 & 25.58 & $20.13-32.50$ & \\
\hline Immunosuppressant condition & & & & 0.6968 \\
\hline No & 193 & 28.91 & $23.19-36.04$ & \\
\hline Yes & 179 & 30.38 & $24.47-37.72$ & \\
\hline McCabe classification & & & & 0.2612 \\
\hline Rapidly fatal & 20 & 41.52 & $23.58-73.11$ & \\
\hline Ultimately fatal & 152 & 31.88 & $25.18-40.37$ & \\
\hline Nonfatal & 200 & 26.85 & $21.57-33.43$ & \\
\hline APACHE II score & & & & 0.0683 \\
\hline$<10$ & 61 & 20.41 & $13.02-31.20$ & \\
\hline $10-19$ & 160 & 28.51 & $22.40-36.29$ & \\
\hline$>20$ & 151 & 34.77 & $27.77-43.53$ & \\
\hline Nature of bacteremia & & & & 0.0298 \\
\hline ICUd acquired & 198 & 24.97 & $20.00-31.17$ & \\
\hline ICU treatede & 166 & 35.67 & $28.61-44.46$ & \\
\hline Severe sepsis & & & & $<0.0001$ \\
\hline No & 104 & 3.32 & $1.49-7.38$ & \\
\hline Yes & 264 & 43.09 & $36.77-50.48$ & \\
\hline Septic shock & & & & $<0.0001$ \\
\hline No & 160 & 8.33 & $5.58-12.43$ & \\
\hline Yes & 201 & 53.91 & $45.42-63.98$ & \\
\hline Inotropic requirement & & & & $<0.0001$ \\
\hline No & 20 & 8.54 & $5.51-13.24$ & \\
\hline Yes & 136 & 47.47 & $40.13-56.16$ & \\
\hline Creatinine & & & & $<0.0001$ \\
\hline$<1.20 \mathrm{mg} / \mathrm{dl}$ & 203 & 22.86 & $18.17-28.75$ & \\
\hline$>1.21 \mathrm{mg} / \mathrm{dl}$ & 145 & 46.31 & $37.25-57.58$ & \\
\hline Antibiotic change during infection & & & & 0.0026 \\
\hline No & 86 & 36.09 & $16.14-26.77$ & \\
\hline Yes & 60 & 20.78 & $29.21-44.58$ & \\
\hline Initial adequate treatment & & & & 0.0002 \\
\hline No & 102 & 43.54 & $33.59-56.45$ & \\
\hline Yes & 247 & 23.21 & $18.95-28.45$ & \\
\hline
\end{tabular}

a 30-day hospital mortality rate per 1000 patient / days, starting from bacteremia onset.

b $95 \%$ Confidence Interval.

${ }^{c}$ Log rank test was used for hypothesis testing.

Intensive Care Unit.

e Bacteremia acquired outside the ICU; main cause of ICU admission.

analysis, some kind of gradient was observed in mortality rates. Despite the balanced severity between exposed groups, a plausible relationship between severity of disease at ICU admission and the later outcome can be suspected.
A significant difference was seen in mortality rates between ICU and nonICU-acquired bacteremia. Length of stay prior to bacteremia, reported as a predictor of mortality in previous studies, did not show a differential effect among resistant and susceptible strains in this analysis.

Etiologic factors for acquisition of methicillin-resistance concurred with widely accepted knowledge that regards previous invasive devices, procedures, and antibiotic exposure as important factors related to hospital-acquired MRSA. In this study's context, the highest rate of invasive procedures was related to Staphylococcus aureus infections, particularly methicillin-resistant ones (39).

The high nosocomial origin registered in this cohort was related to the predominant presence of MRSA in the hospital environment during the study period. Recent reports suggest the emergence of MRSA varieties of community origin as the causative agent of health careassociated infections, with important mortality rates associated with USA 300 clones (40).

\section{Study limitations}

A residual confusion could be related to retrospective nature of the research, especially related to molecular characteristics of some strains that could be related to worse outcomes and were not studied. Prospective studies could lead to a better characterization of widely known molecular diversity of MRSA strains in Latin American countries (41).

This study's main limitation is its retrospective nature, which could lead to some degree of information bias, potentially controlled by the participating institutions' standardization of definitions. Validation by local experts (infection control committees at each institution) and a centralized review committee created to validate the study date attempted to improve information quality.

Another limitation could be the sample size. The study had a sample of 10 subjects less than originally planned. Differences in mortality attributable to methicillin resistance profiles less than a 1.51 hazard ratio could be difficult to see with this sample size. It is worth noting, however, that this study represents one of the largest samples reported to date in the literature.

One of this study's strengths is its exposure-matching by cohorts in a 1:1 ratio within the same institution for the same year (using a random selection process). This allowed for controlling unidentified differences in each hospital environment and health care delivery. 
TABLE 4. Bivariate and multivariate analysis of hospital mortality predictors for Staphylococcus aureus bloodstream infections in critically ill patients in a hospital network in Colombia, 2005-2008

\begin{tabular}{|c|c|c|c|}
\hline Variable & $\begin{array}{l}\text { Unadjusted hazard ratio } \\
\text { (bivariate) }\end{array}$ & $\begin{array}{c}\text { Adjusted hazard ratio } \\
\text { (with methicillin resistance) }\end{array}$ & $\begin{array}{c}\text { Adjusted hazard ratiob } \\
\text { (without methicillin resistance) }\end{array}$ \\
\hline Methicillin resistance & $1.31(0.96-1.79)$ & $0.90(0.62-1.30)$ & - \\
\hline Nosocomial bacteremia & $0.65(0.44-0.95)$ & - & - \\
\hline Catheter-related bacteremia & $0.57(0.41-0.79)$ & - & - \\
\hline APACHE II score & $1.04(1.02-1.07)$ & - & - \\
\hline Multiple organ failure ${ }^{d}$ & $6.03(4.09-8.90)$ & - & - \\
\hline Inotropic requirement ${ }^{d}$ & $5.22(3.26-8.36)$ & $2.58(1.48-4.51)$ & $2.63(1.51-4.58)$ \\
\hline Severe sepsis ${ }^{d}$ & $10.70(5.02-22.83)$ & $6.19(2.16-17.78)$ & $6.05(2.11-17.33)$ \\
\hline Septic shock ${ }^{d}$ & $5.74(3.74-8.82)$ & - & - \\
\hline Sex & $0.66(0.48-0.90)$ & $0.64(0.45-0.91)$ & $0.64(0.45-0.90)$ \\
\hline Creatinine (> $1.21 \mathrm{mg} / \mathrm{dL})$ & $1.87(1.36-2.57)$ & $2.14(1.50-3.06)$ & $2.13(1.49-3.04)$ \\
\hline Age (years) $^{d}$ & $1.02(1.01-1.03)$ & $1.01(1.00-1.02)$ & $1.01(1.00-1.02)$ \\
\hline Antibiotic change during infection & $0.61(0.44-0.85)$ & $0.49(0.34-0.71)$ & $0.51(0.36-0.72)$ \\
\hline Source of infection eradicated & $0.74(0.53-1.02)$ & - & - \\
\hline Initial adequate treatment & $0.56(0.40-0.77)$ & $0.50(0.34-0.73)$ & $0.52(0.36-0.74)$ \\
\hline
\end{tabular}

\section{Conclusions}

This study fills a gap in the Latin American literature on the impact of MRSA in bloodstream infections and confirms the importance of $S$. aureus as a causative pathogen. High mortality rates and increased length of stay confronts health care delivery with a public health problem within the hospital environment itself. Proper microbiological detection, improvement of surveillance networks, and timely control and treatment strategies are some measures that could assist with $S$. aureus containment. Resistance suspicion, source eradication, and suitable antibiotics must complement institutional control programs and infection control policies in Latin America.

There is a widespread need to improve all infection control measures in order to reduce the impact of MRSA in hospital environments. High mortality rates for resistant and susceptible strains justify the need for a broad empirical therapy, rational and controlled, and for the containment of this and other multiresistant micro-organisms, through well established infection control strategies.

Acknowledgements. The authors wish to thank GREBO for its technical and material support, specifically: Hospital Simón Bolívar E.S.E. (Felipe Zamora), Hospital Universitario San Ignacio (Claudia Linares), Fundación Hospital San Carlos (Jaime Saravia, Yaníz Hernández), Hospital El Tunal E.S.E. (Narda Olarte, Alberto Valderrama), Hospital de Occidente Kennedy (Andrés Almánzar, Carlos Alquichire), Fundación Cardio Infantil (Álvaro Arango, Zenaida Montañez), Hospital Universitario de la Samaritana (Carlos Pérez, Beatriz Cuevas, Nancy Osorio), Hospital Universitario Clínica San Rafael (Carlos Saavedra, Henry Oliveros), Saludcoop Jorge Piñeros Corpas (Henry Mendoza, Adriana Martínez), Videlmédica (Johana Ávila, Janeth Delgado), Hospital Central de la Policía Nacional (Henry Mendoza, Flor Ángela Cubides), Hospital Santa Clara E.S.E
(Ibeth Pernet, Claudia Cuellar), Hospital Universitario Mayor (Sonia Castañeda), Hospital Militar Central, Hospital Universitario Fundación Santafé (Guillermo Prada, Stella Vanegas), Centro Policlínico del Olaya (Catherine Rojas), Universidad Nacional de Colombia (Sonia Romero, Andrés Meneses, Natalia Sossa, Gustavo Duarte, Julián Fernández, Andrés José Gómez, María Isabel Ovalle).

This research received financial support from the Departamento Administrativo de Ciencia, Tecnología e Innovación (The Science, Technology, and Innovation Administration, Bogotá, Colombia; grant 110140820452-2007) and the Universidad Nacional de Colombia (National University of Colombia, Bogotá, Colombia; grant DIB-2008 202010011672). Technical support was obtained from the Central Chapter of the Asociación Colombiana de Infectología (Colombian Society of Infectious Diseases), and the Secretaría Distrital de Salud de Bogotá (District Health Department of Bogotá, Colombia).

\section{REFERENCES}

1. PeacockJEJr,MarsikFJ,WenzelRP.Methicillinresistant Staphylococcus aureus: introduction and spread within a hospital. Ann Intern Med. 1980;93:526-32.
2. Espinosa CJ, Cortés JA, Castillo JS, Leal AL. Systematic review of antimicrobial resistance among Gram positive cocci in hospitals in Colombia. Biomedica. 2011;31:27-34.
3. van Duijn PJ, Dautzenberg MJ, Oostdijk EA. Recent trends in antibiotic resistance in European ICUs. Curr Opin Crit Care. 2011;17: $658-65$. 
4. Leal AL, Eslava-Schmalbach J, Alvarez C, Buitrago G, Méndez M; Grupo para el Control de la Resistencia Bacteriana en Bogotá. Endemic tendencies and bacterial resistance markers in third-level hospitals in Bogotá, Colombia. Rev Salud Publica (Bogota). 2006;8 suppl 1;59-70

5. Shorr AF. Epidemiology and economic impact of meticillin-resistant Staphylococcus aureus: review and analysis of the literature. Pharmacoeconomics. 2007;25:751-68.

6. Harbarth S, Rutschmann O, Sudre P, Pittet D. Impact of methicillin resistance on the outcome of patients with bacteremia caused by Staphylococcus aureus. Arch Intern Med. 1998;158:182-9.

7. Cosgrove SE, Sakoulas G, Perencevich EN, Schwaber MJ, Karchmer AW, Carmeli Y. Comparison of mortality associated with methicillin-resistant and methicillin-susceptible Staphylococcus aureus bacteremia: a meta-analysis. Clin Infect Dis. 2003:36:53-9.

8. Cosgrove SE, Qi Y, Kaye KS, Harbarth S, Karchmer AW, Carmeli Y. The impact of methicillin resistance in Staphylococcus aureus bacteremia on patient outcomes: mortality, length of stay, and hospital charges. Infect Control Hosp Epidemiol. 2005;26:166-74.

9. Rubio-Terrés C, Garau J, Grau S, MartinezMartinez L, Cast of Resistance Study group. Cost of bacteraemia caused by methicillinresistant vs. methicillin-susceptible Staphylococcus aureus in Spain: a retrospective cohort study. Clin Microbiol Infect 2010;16: 722-8.

10. van Hal SJ, Jensen SO, Vaska VL, Espedido BA, Paterson DL, Gosbell IB. Predictors of mortality in Staphylococcus aureus Bacteremia. Clin Microbiol Rev. 2012;25:362-86.

11. Kang CI, Song JH, Chung DR, Peck KR, Ko KS, Yeom JS, et al.; Asian Network for Surveillance of Resistant Pathogens (ANSORP) Study Group. Clinical impact of methicillin resistance on outcome of patients with Staphylococcus aureus infection: a stratified analysis according to underlying diseases and sites of infection in a large prospective cohort. J Infect. 2010;61:299-306.

12. Rello J, Ricart M, Mirelis B, Quintana E, Gurgui M, Net A, et al. Nosocomial bacteremia in a medical-surgical intensive care unit: epidemiologic characteristics and factors influencing mortality in 111 episodes. Intensive Care Med. 1994;20:94-8.

13. Blot SI, Vandewoude KH, Hoste EA, Colardyn FA. Outcome and attributable mortality in critically ill patients with bacteremia involving methicillin-susceptible and methicillin-resistant Staphylococcus aureus. Arch Intern Med. 2002;162:2229-35.

14. Harbarth $S$, Ferrière K, Hugonnet $S$, Ricou B, Suter P, Pittet D. Epidemiology and prognostic determinants of bloodstream infections in surgical intensive care. Arch Surg. 2002;137:1353-9.

15. Thompson DS. Methicillin-resistant Staphylococcus aureus in a general intensive care unit. J R Soc Med. 2004;97:521-6.

16. Gastmeier P, Sohr D, Geffers C, Behnke M, Daschner F, Rüden H. Mortality risk factors with nosocomial Staphylococcus aureus infec- tions in intensive care units: results from the German Nosocomial Infection Surveillance System (KISS). Infection. 2005;33:50-5.

17. Oztoprak N, Cevik MA, Akinci E, Korkmaz M, Erbay A, Eren SS, et al. Risk factors for ICU-acquired methicillin-resistant Staphylococcus aureus infections. Am J Infect Control. 2006;34:1-5.

18. Thompson DS, Workman R, Strutt M. Contribution of acquired meticillin-resistant Staphylococcus aureus bacteraemia to overall mortality in a general intensive care unit. J Hosp Infect. 2008;70:223-7.

19. Ho KM, Robinson JO. Risk factors and outcomes of methicillin-resistant Staphylococcus aureus bacteraemia in critically ill patients: a case control study. Anaesth Intensive Care. 2009;37:457-63.

20. Ibrahim EH, Sherman G, Ward S, Fraser VJ, Kollef $\mathrm{MH}$. The influence of inadequate antimicrobial treatment of bloodstream infections on patient outcomes in the ICU setting. Chest. 2000;118:146-55.

21. Schramm GE, Johnson JA, Doherty JA, Micek ST, Kollef MH. Methicillin-resistant Staphylococcus aureus sterile-site infection: The importance of appropriate initial antimicrobial treatment. Crit Care Med. 2006;34:2069-74.

22. Cortés JA, Garzón DC, Navarrete JA, Contreras KM. Impact of inappropriate antimicrobial therapy on patients with bacteremia in intensive care units and resistance patterns in Latin America. Rev Argent Microbiol. 2010;42:230-4.

23. Horan TC, Andrus M, Dudeck MA. CDC/ NHSN surveillance definition of health careassociated infection and criteria for specific types of infections in the acute care setting. Am J Infect Control. 2008;36:309-32.

24. Friedman ND, Kaye KS, Stout JE, McGarry SA, Trivette SL, Briggs JP, et al. Health careassociated bloodstream infections in adults: a reason to change the accepted definition of community-acquired infections. Ann Intern Med. 2002;137:791-7.

25. Carmeli Y, Troillet N, Karchmer AW, Samore $\mathrm{MH}$. Health and economic outcomes of antibiotic resistance in Pseudomonas aeruginosa. Arch Intern Med. 1999;159:1127-32.

26. Knaus WA, Draper EA, Wagner DP, Zimmerman JE. APACHE II: a severity of disease classification system. Crit Care Med. 1985;13:818-29.

27. Craven DE, Kunches LM, Lichtenberg DA, Kollisch NR, Barry MA, Heeren TC, McCabe WR. Nosocomial infection and fatality in medical and surgical intensive care unit patients. Arch Intern Med. 1988. May;148(5):1161-8.

28. Charlson ME, Pompei $P$, Ales KL, MacKenzie CR. A new method of classifying prognostic comorbidity in longitudinal studies: development and validation. J Chronic Dis. 1987;40:373-83.

29. Levy MM, Fink MP, Marshall JC, Abraham E, Angus D, Cook D, et al.; SCCM/ESICM/ ACCP/ATS/SIS. 2001 SCCM/ESICM/ACCP/ ATS/SIS International Sepsis Definitions Conference. Crit Care Med. 2003;31:1250-6.

30. Clinical and Laboratory Standards Institute. Performance standards for antimicrobial susceptibility testing; 19th informational supple- ment. Wayne, PA: Clinical and Laboratory Standards Institute; 2009.

31. Rabe-Hesketh S. A handbook of statistical analyses using Stata. Third ed. Boca Raton: CRC Press; 2004

32. Gastmeier P, Sohr D, Geffers C, Behnke M, Rüden H. Risk factors for death due to nosocomial infection in intensive care unit patients: findings from the Krankenhaus Infections Surveillance System. Infect Control Hosp Epidemiol. 2007;28:466-72.

33. Ammerlaan $H$, Seifert $H$, Harbarth $S$, BrunBuisson C, Torres A, Antonelli $\mathrm{M}$, et al.; European Practices of Infections with Staphylococcus aureus (SEPIA) Study Group. Adequacy of antimicrobial treatment and outcome of Staphylococcus aureus bacteremia in 9 Western European countries. Clin Infect Dis. 2009;49:997-1005.

34. Marchaim D, Kaye KS, Fowler VG, Anderson DJ, Chawla V, Golan Y, et al. Case-control study to identify factors associated with mortality among patients with methicillin-resistant Staphylococcus aureus bacteraemia. Clin Microbiol Infect. 2010;16:747-52.

35. Alvarez Lerma F, Palomar $M$, Insausti J, Olaechea P, Cerdá E, Sánchez Godoy J, et al.; Grupo de Estudio Nacional de Vigilancia de Infección Nosocomial en UCI. Infecciones nosocomiales por Staphylococcus aureus en pacientes críticos en unidades de cuidados intensivos. Med Clin (Barc). 2006;126:641-6.

36. Wang FD, Chen YY, Chen TL, Lin YT, Fung $\mathrm{CP}$. Risk factors and mortality of nosocomial infections of methicillin-resistant Staphylococcus aureus in an intensive care unit. J Crit Care. 2011;26:82-8.

37. Alberti C, Brun-Buisson C, Goodman SV Guidici D, Granton J, Moreno R, et al. European Sepsis Group. Influence of systemic inflammatory response syndrome and sepsis on outcome of critically ill infected patients. Am J Respir Crit Care Med. 2003;168:77-84.

38. Combes A, Luyt CE, Trouillet JL, Nieszkowska A, Chastre J. Gender impact on the outcomes of critically ill patients with nosocomial infections. Crit Care Med. 2009;37:2506-11.

39. Moreno CA, Rosenthal VD, Olarte N, Gomez WV, Sussmann O, Agudelo JG, et al. Deviceassociated infection rate and mortality in intensive care units of 9 Colombian hospitals: findings of the International Nosocomial Infection Control Consortium. Infect Control Hosp Epidemiol. 2006;27:349-56.

40. Alvarez CA, Yomayusa N, Leal AL, Moreno J, Mendez-Alvarez S, Ibañez M, et al. Nosocomial infections caused by community-associated methicillin-resistant Staphylococcus aureus in Colombia. Am J Infect Control. 2010;38:315-8.

41. Rodríguez-Noriega E, Seas C, GuzmánBlanco M, Mejía C, Alvarez C, Bavestrello L, et al. Evolution of methicillin-resistant Staphylococcus aureus clones in Latin America. Int J Infect Dis. 2010;14:e560-6.

Manuscript received on 10 April 2011. Revised version accepted for publication on 1 July 2012 
RESUMEN Objetivo. Evaluar los factores de riesgo asociados con la aparición de bacteriemia por Staphylococcus aureus resistente a la meticilina (MRSA), su pronóstico y los factores determinantes de la mortalidad en pacientes gravemente enfermos en Colombia.

Mortalidad en pacientes gravemente enfermos con bacteriemia por Staphylococcus aureus resistente a la meticilina: un estudio multicéntrico de cohortes en Colombia

Palabras clave
Métodos. Estudio retrospectivo multicéntrico de cohortes realizado en el período del 2005 al 2008 en 16 instituciones de atención de salud de referencia públicas y privadas de Bogotá, Colombia, que forman parte de una red nacional de vigilancia epidemiológica y de una red hospitalaria de 4469 camas. Se analizaron la aparición de resistencia a la meticilina y la mortalidad mediante análisis descriptivos y de tiempo transcurrido hasta un suceso; se estableció un modelo multifactorial de regresión de riesgos proporcionales de Cox para evaluar la asociación entre la resistencia a la meticilina y la mortalidad.

Resultados. Se estudiaron 372 pacientes: 186 con bacteriemia por MRSA, apareados aleatoriamente con 186 con bacteriemia por Staphylococcus aureus sensible a la meticilina (MSSA). La cirugía previa, el tratamiento con antibióticos y las infecciones intrahospitalarias se asociaron independientemente con la resistencia a la meticilina. El MRSA provocó hospitalizaciones más prolongadas en los sobrevivientes (mediana de 24 frente a 18 días, $P=0,014$ ). Los factores predictivos de mortalidad fueron: la edad del paciente, un nivel de creatinina superior a $1,21 \mathrm{mg} / \mathrm{dl}$ al ingresar en la UCI, la septicemia grave y el requerimiento de inotrópicos. El tratamiento antimicrobiano apropiado y el cambio de tratamiento antimicrobiano constituyeron factores protectores independientes, igual que el sexo masculino.

Conclusiones. La resistencia a la meticilina per se no fue un factor pronóstico independiente de la mortalidad. Las condiciones previas, como la edad, la insuficiencia renal inicial, la septicemia grave y el requerimiento de inotrópicos explicaron la mortalidad observada. El tratamiento antimicrobiano apropiado seguía siendo un factor protector. Es obligatorio hacer un llamamiento para mejorar las medidas de control de las infecciones en Colombia y en otros contextos similares.

Infecciones bacterianas; Staphylococcus aureus resistente a meticilina; evaluación de resultado (atención de salud); factores de riesgo; mortalidad; Colombia. 